\title{
AZ ANGOL SZAKKÉPZÉSI ÉS TOVÁBBKÉPZÉSI REFORMOK A Brexit ÁRNYÉKÁBAN
}

\author{
ZOLNAI ERIKA
}

Debreceni Egyetem Nevelés- és Művelődéstudományi Intézet

\begin{abstract}
A lassan harminc éve tartó angol oktatási reformok hangsúlyai 2016 óta a szakképzési és továbbképzési rendszer modernizálására helyeződtek. A tanulmányban az angol kormányok három hullámának (Thatcher kormánya és az „Új Jobboldal”; a Munkáspárt kormányai; Cameron koalíciós kormányai és a mai May-kormány) oktatáspolitikáján keresztül röviden áttekintjük a folyamat legfontosabb intézkedéseit és azok pártpolitikai és oktatáspolitikai vetületét. A koalíciós kormány Michael Gove oktatási miniszter irányításával 2010-től az oktatási követelmények és az ellenőrzés szigorítása mellett döntött, elsősorban a 16-19 éves korosztály képzési helyzetének javítása céljából. Az intézkedéseket intenzív szakmai vita kíséri, melyben finanszírozási és szakmai szempontok egyaránt megfogalmazódnak.
\end{abstract}

Kulcsszavak: szakképzés, reform, Anglia, Brexit

Since 2016, the focus of the almost 30 year old English educational reform has turned toward the development of the VET System. In this paper we review the most important measures and political dimensions of this process. We discuss this topic through the educational policies of three waves of English Governments: 1) Thatcher's government and the New Right; 2) Governments of Labour Party; 3) Cameron's coalition governments and present day May's Government. Under the direction of Michael Gove Education Minister from 2010 the coalition government decided to increase education requirements and control. The main goals of their measures were to help the 16-19 year olds to enter the world of work successfully. The evaluation is accompanied by intense professional debates, which contains several financial and professional aspects.

Keywords vocational education and training, reform, England, Brexit

Levelező szerző: Zolnai Erika, Debreceni Egyetem, Nevelés- és Művelődéstudományi Intézet, 4002 Debrecen, Pf. 400. E-mail: zolnai.erika@arts.unideb.hu 
A $z$ angol oktatási reformokat a szakirodalom legalább a legutóbbi harminc év távlatában tárgyalja, az 1988-as oktatási törvényig tekintenek vissza, hiszen a modern közoktatás legmeghatározóbb folyamatai innen indulnak, és Thatcher neoliberális közigazgatási reformjáig nyúlnak vissza.

A reformok hosszú évtizedekre visszatekintő centralizációs folyamataiban a szakképzés korszerüsítése kulcskérdéssé vált. A gazdasági versenyképesség és a társadalmi folyamatok nyomására a politikai döntéshozók igyekeztek olyan oktatási rendszert kialakítani, amely egyszerre képes a társadalmi integráció és a munkaerőpiac elvárásainak is eleget tenni. A tanulmányban elsősorban a 14-18 éves korosztályt érintő szakképzési változások új irányait tekintjük át, különös tekintettel az utóbbi húsz év kormányzati intézkedéseire.

Az angol szakmai és továbbképző rendszert és a 14-18 évesek képzési helyzetét a korai szelekciós mechanizmusok és a felsőoktatási expanzió egyaránt megnehezíti. A 2007-es gazdasági válság idején a közoktatást érintő forráskivonás a szakképzésben súlyosabban jelentkezett, mint a többi területen. Ugyanakkor a legtöbb változás, beavatkozás, intézményi fejlesztés és ezzel együtt kritika is erre az oktatási szektorra irányult.

A változások részletes ismertetése messze túlmutat kereteinken, de megkerülhetetlen, hiszen a legfrissebb elemzések ezt tekintik a problémák egyik fó forrásának. A nyolcvanas évek elejétől 28 új jogszabály és hat különböző minisztériumi ügynökség foglalkozott a szakképzéssel. 48 illetékes államtitkár váltotta egymást, miközben egyetlen szakképzésben illetékes hatóság sem maradt fenn tíz évnél tovább (Norris-Adams 2017). $\mathrm{A} z$ instabilitás rossz hatással van az intézményi emlékezetre és a kiszámíthatóságra, ${ }^{1}$ ami a tanulók számára nehezen követhető tanulási utakat eredményez. A szakképzési programok egyszerűsítését minden oktatási jelentés javasolta, de a megvalósítás rendre ellenállásba ütközött. Végül a kormány 2016-ban bejelentette a 16 éven felüliek képességtervét (Post-16 Skills Plan 12 in July 2016²), melyben a széttagolt képesítési struktúrát egy világosabb, tizenöt lehetséges képzési irányt tartalmazó szakképesítési struktúrára cserélte le, a Gyakornoki rendszer (Modern Apprenticeships) jelentős kiterjesztése mellett.

Hogy a piaci viszonyok erősítése hogyan hat a szakképzésre, arra számos pozitív példával találkozunk az erős szakképzési rendszerrel rendelkező fejlett európai országokban (Németország, Svájc, Ausztria, Franciaország, Dánia). A megoldás azonban nem ilyen egyszerü, hiszen egyes szerzők kifejezetten azt fogalmazzák meg, hogy az említett nemzetek politikai gyakorlata különbözik az Egyesült Királyságétól, ami kihat a szakképzési rendszer stabilitására, illetve változékonyságára (Norris-Adams 2017).

A rendkívüli széttagoltság és a gyakori változások mellett az angol szakképzés másik neuralgikus pontja, hogy túl korán válik szét az akadémiai és a szakmai képzés. Az első továbbtanulási döntés tizenegy éves korban történik, de ekkor a tanulók még éretlenek a pályaválasztási döntésekhez, és a tanulási utakon a későbbiekben nehéz változtatni. Az elemzések szerint a szakmai képesítések alacsony presztízsű, rossz minősítésű végzettségeket jelentenek, a meglévő képzési keretek viszont akadályozzák a társadalmi mobilitást. A hátrányosabb helyzetü csoportok kevésbé férnek hozzá a színvonalas iskolákhoz, jól képzett tanárokhoz, és így később a jól fizető állásokhoz is. A felsőoktatás magas

Lord Adonis, Shadow Infrastructure Minister: https://www.cityandguilds.com/news/october-2014/ skills-policy-review\#.XP-bXxYzbIX [Valamennyi internetes forrás letöltve: 2019. 10. 17.]

2 Post-16 Skills Plan 12 in July 2016: https://assets.publishing.service.gov.uk/government/uploads/system/ uploads/attachment_data/file/536043/Post-16_Skills_Plan.pdf 
költségei számos diploma esetében nem térülnek meg, miközben a munkaerőpiacon az egyetemi végzettséget nem igénylő középfokú szakképzettséggel végezhető állásokat a munkáltatók diplomás fiatalokkal töltik be (Nuffield Review 2009; Wolf 2011; House of Lords 2016; Wolf-Sellen-Dominguez-Reig 2016).

A harmadik fontos tényező az ebből következő társadalmi polarizálódás. A társadalmi mobilitás növelése mindegyik párt oktatási programjának központi eleme, és az oktatási reformok legfőbb indoka (Neumann 2008; Young 2011). A szakképzés tehát az oktatási rendszerrel kapcsolatos viták főszereplőjévé vált. Különböző narratívákkal ugyan, de az éppen kormányon lévő és az ellenzéki pártok is hasonló intézkedések bevezetését tervezik azzal a céllal, hogy a szakképzést veszélyeztetett helyzetéből eredményesebbé tegyék. Pártpolitikai nézőpontoktól függetlenül válaszokat kell találni a 21. század oktatási kihívására. A fó kérdés, hogy miként lehetséges kormányzati eszközökkel egyensúlyt teremteni az akadémiai tudás és a szakmai képességek, az iskolai tanulás és a munkahelyi gyakorlat, az elitképzés és a szakképzés, valamint a versengés és az együttmüködés attitüdjei között?

\section{Az angol szakképzés struktúrája, a tanügyigazgatás főbb szempontjai}

A felsőoktatás - az autonóm és változatos egyetemi képzés mellett - a bigher education institute-okban (HEI) és a further education college-okban (FE College) is biztosít felsőoktatási kurzusokat a 18 éves kor feletti fiatalok és a felnőttek számára. Ezek tandíjas képzések, de a tandíjakhoz tanulmányi hitelek kapcsolódnak. A felsőoktatási expanzió során a hallgatói létszám jelentősen megnőtt, de széles rétegek számára még így sem elérhető. A szakképzésbe ennek következtében nagy számban kerülnek be azok, akiknek nem sikerül letenni az egyetemi felvételhez szükséges vizsgákat. A felsőfokú szakképzések és a felsőoktatás továbbképzési kínálatának elemzése kívül esik a tanulmány fókuszán, bár alternatív továbbtanulási utakat kínálnak a középfokú szakképzés után, illetve azok mellett.

$\mathrm{A} z$ alap- és középfokú szakképzés és továbbképzés szintén összetett rendszer. Egyrészt magában foglalja az időről időre megújuló Gyakornoki rendszert (Modern Apprenticeships 1994-től; English Apprenticeships 2020-tól), ami munkaalapú képzést jelent 16-24 éves korig rész-vagy teljes munkaidőben. A hozzáférést napjainkban kormányzati eszközökkel bővítik a kis- és középvállalkozások irányába, a gyakornoki szerződések költségeit pályázati úton államilag biztosítják. Másrészt az iskolarendszerü továbbképzések jelentik a szakképzés egyéb formáit.

$\mathrm{A} z$ iskolarendszerű továbbképző és szakképző intézmények fenntartói, illetve tulajdonosi szerkezete összetett. Az utóbbi évek iskolaátalakítási és -alapítási programjai a független egyházi és alapítványi fenntartású intézmények (academies, free schools, studio schools, city academies, UTC) számát jelentős mértékben növelték, szemben a hagyományos szakképzési programokat nyújtó főiskolai formákkal (sixth form collegies, further colleges). A független iskolák állami és magánfinanszírozásúak, a tanterveiket tekintve és a személyi, tárgyi feltételekben nagyobb szabadsággal rendelkeznek, mint az utóbbi önkormányzati fenntartású és ellenőrzésü intézmények (LEA - Local Educational Agency). Az intézmények külső szakmai ellenőrzését az Ofsted (Office for 
Standards in Education, Children's Services and Skills) ${ }^{3}$ végzi. A finanszírozott (statefounded boarding schools - maintained schools) iskolákra szigorúbb müködési feltételek vonatkoznak, mint az ún. független iskolákra (Zolnai 2014).

$\mathrm{Az}$ iskolarendszerben az első szelekció tizenegy éves korban történik, amikor a szelektív magángimnáziumokba vagy a részben szelektív állami gimnáziumokba felvételizhetnek a tanulók. Aki nem ezt az egyetemhez vezető utat választja vagy nem sikerül a felvételije, esetleg nem tudja a család a tandíjat, illetve a bentlakás költségeit fizetni, azok a középiskolák fent említett formáiban tanulnak tovább.

Mindegyik középiskola biztosít munkatapasztalat-szerzést, illetve szakmai végzettségekre is felkészítenek (1.2. 3. szinteken). Az intézményeknek meg kell felelniük a képzési kimenetekkel kapcsolatos elvárásoknak. Az alaptárgyak (angol, matematika, természettudományi tárgyak, idegen nyelv, humán tárgyak/történelem) mellett egyéb alkalmazott és szakmai tárgyakat is tanulnak az iskola kínálatából. A tanulóknak a képzési idő során a törvény által előírt számú és a Nemzeti Alaptantervben (National Curriculum at Key Stage 4) meghatározott tartalmú GCSE vizsgát kell tennie 16 éves korában, ami a kötelező iskolarendszerü oktatás végét jelenti. A GCSE vizsga megszerzésével a 16 éves kor utáni oktatás már többféle: lehet teljes munkaidős iskolarendszerü vagy munkaalapú, mint a Gyakornoki rendszer, illetve munkahelyi tanfolyamok, valamint részidős képzések, ami mellett dolgozhatnak is a szakképzés résztvevői. 18 éves korig kötelező valamilyen képzésben részt venni.

A szakképzés, illetve továbbtanulás egyes iskolatípusokban 14-18 éves korig tart (UTC), a Further Colleges és a Sixthform Colleges 14-18 éves korban jellemző. Az egyes képző intézmények kínálatáról és költségeiről az iskolák honlapja mellett információs adatbázisokból is tájékozódhatnak a jelentkezők. A képzés végén NVQ 1, 2, 3 szinteken lehet szakmai képesítéseket szerezni a független vizsgabizottságok előtt.

A tanügyigazgatással kapcsolatos kritikák főként a standardizált teljesítménymérésekkel kapcsolatosak. Az iskolai stressz, a tanárok frusztrációjának növekedése és az ebből fakadó pályaelhagyás, munkahelyi fluktuáció és végül a tanulói vizsgateljesítmények csökkenése (kevesebb sikeres GCSE vizsga, $A$ szintű vizsgák csökkenő száma, valamint alacsonyabb eredményei) improduktív hatású. Az iskolák közötti különbségek növekedtek.

A kritikák másik csoportja a különböző fenntartású intézmények eltérő szabályaira vonatkozik. A LEA-ák (Local Education Agency) által fenntartott intézmények esetében a törvény által elöírt oktatási kereteket szigorúan számon kérik, míg a független iskolák alkalmazhatnak akár képesítés nélküli tanárokat is a költségek csökkentése céljából, így jelentősen eltérhetnek az elöírásoktól. Szintén az egyre szaporodó független iskolákkal szemben fogalmazódik meg a szülők kiszolgáltatottsága, mivel csökken a beleszólásuk az iskola életébe és a döntésekbe. Az így kialakuló kettős mércét sokan kifogásolják, hiszen ez a rendszer a kedvező társadalmi helyzetü diákokat oktató önkormányzati iskolák müködésének kedvez, a nehezebb társadalmi hátterüeket tanítók viszont a teljesítményelvárásoknak kevésbé tudnak megfelelni, és érdekeltté válnak abban, hogy akadémiává alakuljanak. A korábbi és a jelenlegi kormány a nyolcvanas években beveze-

Azúj keretrendszer oktatástartalmának ellenőrzésére (2019. május 14.): https://www.gov.uk/government/ consultations/education-inspection-framework-2019-inspecting-the-substance-of-education/educationinspection-framework-2019-inspecting-the-substance-of-education 
tett akadémiai forma bővítése mellett annak ellenére kiáll, hogy rengeteg kritika éri az alacsony színvonal, az ellenőrizetlen gazdálkodás miatt, és az utóbbi években az Ofsted javaslatára számos akadémia és UTC bezárásra került.

A közoktatást és a szakképzést 2017-ben egységes irányítás és finanszírozás alá helyezte az állam. Az Oktatási Minisztérium két ügynökségét összevonták, és mindkét terület irányítását és finanszírozását egységesen az Oktatás és Szakképzés Finanszírozási Ügynökség (Education and Skills Funding Agency) látja el. Az egyesítés célja a jobb szolgáltatás és az elszámoltathatóság, valamint az szolgáltatások kiszámítható finanszírozása volt (Justine Greening oktatási miniszter, 2017²).

$\mathrm{Az}$ Ofsted felelős a nemzeti oktatási keretrendszer normáinak a megvalósításáért, a tanfelügyelöi rendszer működésért, a tanulói, tanári és iskolai teljesítmények minősítéséért, a sztenderdizált tesztek kidolgozásáért. Az iskolai teljesítmények alapján nyilvános iskolai rangsorokat állít fel. Javaslatot tesz egyes iskolák müködésének megszüntetésére. Felállítása óta az Ofsted működését sok kritika érte, a túlzó elvárások, a teljesítménynyomás mind a tantestületekre, mind a tanulókra egyaránt rossz hatással volt. Az ezzel kapcsolatos visszajelzések hatására a legutóbbi törvénymódosítással (2019) az Ofsted mellett az oktatás szereplőit széles körben bevonják az ellenőrzésbe, ezzel is hangsúlyozva, hogy az ellenőrzés célja olyan fejlesztés, ami a tanulók, a szülők és az iskolák érdekeit egyaránt szolgálja.

$\mathrm{Az}$ alulteljesítő és / vagy rosszul gazdálkodó iskolák számára egy cselekvési terv kidolgozását javasolják, melyhez az érintett iskola forrásokra pályázhat az Oktatási Minisztérium erre a célra elkülönített alapjából (Strategic college improvement fund).5 A fejlesztés sikeressége érdekében az anyagi segítség mellett szakmai támogatást is kap. A támogatás feltétele, hogy partnerségi megállapodást kössön egy-egy jól teljesítő iskolával és közösen dolgozzanak ki fejlesztési akciótervet a működés javítása céljából. A szakmai fejlesztések minden fél számára előnyösek, minden résztvevő iskolában tartalmaznak tanári továbbképzéseket, taneszközfejlesztést és infrastrukturális beruházásokat. A jó gyakorlatot kínáló iskola a folyamatban továbberősíti a szakmai tapasztalatát, miközben a tanárok is részesednek a juttatásokból, és infrastrukturális fejlesztést is kapnak. Ez jól példázza, hogy miközben a tanügyigazgatás a centralizált, összehangolt irányítás és ellenőrzés elve mentén és felülről kezdeményezett beavatkozások segítségével működik, ugyanakkor a fejlesztés tartalmát, eszközrendszerét a helyi szükségletekhez igazítják. Az iskolák a részletek kidolgozásában és megvalósításában nagy önállóságot kapnak, támaszkodnak a meglévő jó gyakorlatok tapasztalataira ${ }^{6}$

A több évtizeden keresztül zajló centralizáció csökkentette az önkormányzatok és a szülők szerepét a képzés irányításában és ellenőrzésében. A finanszírozás területén az állami források mellett a korábban államilag, illetve megyei önkormányzatok által finanszírozott iskolák kiszervezésével (független akadémiákká) az egyéb gazdasági szereplők, illetve a felhasználói csoportok bevonásával növelték a magánforrások arányát. A költségek megosztása csökkenti az állam oktatási költségeit, de a tervezés és ellenőrzés lehetőségét is. Felülről jövő kezdeményezésekkel igyekeznek motiválni a gazdasági

4 https://www.gov.uk/government/news/new-agency-to-provide-joined-up-education-and-skills-funding

5 Strategic college improvement fund: https://www.gov.uk/government/publications/strategic-collegeimprovement-fund-process-evaluation

6 Burke 2018: https://feweek.co.uk/2018/03/29/14-colleges-to-benefit-from-strategic-collegeimprovement-fund-pilot-announced/ 
szereplőket arra, hogy bekapcsolódjanak a szakképzésbe. Ez egyrészt a finanszírozásra vonatkozik (független iskolák támogatóiként), másrészt a képzések tartalmának kidolgozására, harmadrészt pedig a munkatapasztalat, illetve gyakorlati hely biztosítása a különböző képzési programokban tanulók számára.

\section{Oktatási reform: minőség és/vagy oktatási egyenlőség?}

A fejlett országok oktatási rendszerei esetében a növekvő oktatási kiadásokkal nem nő arányosan az oktatás eredményessége, ${ }^{7}$ ezért egyre nagyobb figyelem irányul a fenntarthatóság vizsgálatára, és felértékelődnek a reformok nem anyagi jellegü összetevői. Miközben megnőtt a kötelező képzésben töltött idő, mindenki számára elérhetővé vált az oktatás, felértékelődött az oktatás teljesítményének (minőség, oktatási tartalmak megfelelősége) és az oktatási egyenlőtlenségek kérdése. Ezzel együtt csökken a szakképzésben való részvétel, így a diplomások számának növekedése mellett nő az alacsony szakmai végzettséggel rendelkezők száma, akik a munkaerőpiacon csekély eséllyel helyezkednek el.

A szakképzés helyzetét az általa nyújtott képzések értékével, a megszerezhető jövedelmi viszonyokkal, társadalmi megbecsüléssel, státusszal szokás jellemezni. Ebben a tekintetben az angol rendszer belső kritikusai szerint alulteljesít a fejlett európai országok mögött (Nuffield Review 2009; Wolf Review 2011; Politeia Report 2018). Az oktatási reformok a minőség és az oktatási egyenlőtlenségek csökkentése között egyensúlyoznak, a célok eléréshez szükséges eszközökben még az egyes parlamenti pártokon belül sincs konszenzus (White 2010; Young 2008; Young 2011).

A bal- és jobboldal oktatáspolitikája legmarkánsabban az oktatási normák területén válik el. Míg a munkáspárti kormányok a kompetenciaalapú oktatás felől közelítettek, addig a konzervatív kormányok az elitképzéshez köthető tényalapú megközelítéshez való visszatérést népszerüsítették, a hagyományok, a kultúra értékeinek megőrzésével érvelve.

\section{Oktatási reformok a szakképzés partvonalán}

A kötelező állami közoktatás struktúrái és hagyományai a 19. század első felére nyúlnak vissza, megőrizve az egyes intézmények formai és tartalmi gyökereit. Az évek során a rendszer újabb és újabb elemmel bővült, mára egy erősen differenciált, sok párhuzamos és egymást átfedő elemből felépülő, bonyolult rendszer, melyben különböző fenntartási és finanszírozási (magán, állami, önkormányzati, vegyes, egyházi) keretek nehezítik az eligazodást. A szakképzés sokszínűsége a végzettségek sokféleségében is megjelenik. A reformok igyekeztek ezt is egyszerüsíteni és átláthatóvá tenni többek között a képesítések egyenértékűségének meghatározásával. A folyamatos átalakítási szándék és fejlesztés ellenére az angol még mindig Európa legkorábbi életkorban specializáló, erősen szelektív oktatási rendszere (Zolnai 2014).

Barber-Mourshed 2007: https://www.mckinsey.com/industries/social-sector/our-insights/how-the-worldsbest-performing-school-systems-come-out-on-top 


\section{A modernizálás elsö bulláma: Margaret Thatcher és John Major kormányzása} (1979-1997)

Thatcher konzervatív kormányzása a közigazgatásra is kiterjesztette a neoliberális elveket (Neumann 2008). Az 1979-es ${ }^{8}$ és a 80 -as oktatási törvény ${ }^{9}$ utat nyit az oktatási kínálat és kereslet önszabályozásának. Azt várták ettől, hogy segíti a gyermekek változó szükségleteihez és a lokális különbségekhez való alkalmazkodást. Ez a természetes egyensúly számos európai országban hatékonyan müködik, azonban a társadalmi megosztottság a különbségek növekedéséhez vezethet (Young 2011). John Major kormányzása alatt a várakozásokkal szemben folytatódtak a korábbi évek költségvetési megszorításai, és az intézkedések tovább növelték a szakadékot az akadémiai és a szakmai képzés között, mivel a finanszírozás különbsége tovább nőtt a gimnáziumok javára. J. Major elkötelezett volt az elitoktatás, az önkormányzatok befolyásának a csökkentése mellett, miközben továbbra is élesen bírálta a pedagógusokat, ahelyett, hogy szövetségesként összefogott volna velük a változások érdekében, őket hibáztatta az oktatási kudarcokért.

A kritikák szerint a változások az egyéni vállalkozásokat erősítették, melyek központilag ellenőrzött keretek között versengenek az ügyfelekért, miközben megszüntették a helyi tervezés lehetőségét, így a károsnak ítélt szelekciót nem lehetett korrigálni. Közben a legjobban működő intézmények felsőoktatási jogokat kaptak, müködésük kikerült a középfokú szakképzési keretből (Gillard 2018). Mindez a különbségek növekedéséhez vezetett.

$\mathrm{A} z$ időszak végén a figyelem újra a tizenhat éves korosztály képzésére irányult (Dearing Review $1996^{10}$ ), megállapították, hogy a képzési költségek csekély megtérülésüek, és alacsony szintü végzettségeket eredményeznek.

\section{Baloldali beavatkozások: a Munkáspárt szakképzési kezdeményezései (1997-2010)}

A Munkáspárt Tony Blair vezetésével még ellenzékben kidolgozta a British Baccalaureate bevezetésére vonatkozó javaslatot, ami a 16-19 évesek számára átjárhatóságot teremtett az egyetemi és a szakképzés között. Az 1950-ben kidolgozott GCE vizsga a szelektív gimnáziumi oktatás céljaira épült, és az ezekben történő továbbtanulás céljait szolgálta. A képesítési reformok következtében a GCSE vizsga (1986) egységesebbé tette a vizsgák rendszerét (Imre 1995), de az ún. akadémiai és a szakképzési tanulási utat nem kötötte össze, megmaradt a túl korai döntés a kettő közötti választásban. Az elképzelések szerint egységes vizsgarendszert vezettek volna be, mely egyetlen, ún. Advanced Diplomát (British Baccalaureate) adott volna a középiskola végén. Abban bíztak, hogy a rendszer növeli a 16 éves kor után teljes nappali tagozaton tovább tanulók számát, de azok számára is biztosítja a továbbtanulás esélyeit, akik csak részidős képzéseket tudnak vállalni (Finegold et al. 1990). Kiálltak az oktatási piac szabályozása mellett, és alternatív javaslatokat dolgoztak ki a nemzeti tantervre is. Ugyanakkor a baloldal sem volt soha egységes az oktatást illetö-

\footnotetext{
1979-es oktatási törvény: http://www.educationengland.org.uk/documents/acts/1979-education-act.pdf 1980-as oktatási törvény: http://www.educationengland.org.uk/documents/acts/1980-education-act.pdf

10 Dearing Rewiew 1996: https://files.eric.ed.gov/fulltext/ED403388.pdf
} 
en, különösen megosztott volt a comprehensive iskolák ${ }^{11}$ kérdésében (Lawton 2005, idézi Gillard 2018). Sokan úgy érezték, hogy ezek az iskolák nem adnak megfelelő felkészítést az egyetemi továbbtanuláshoz, és szülőként is inkább a jobb esélyeket nyújtó gimnáziumokat választják, ami felvételivel és gyakran oktatási költségekkel is jár.

Amint kormányra kerültek, azonnal teljesítették az ígéreteiket. Fokozatosan kivezették az ún. támogatott belyek rendszerét, melyet a Thatcher-kormány vezetett be, és évente harmincezer magán- vagy egyházi iskolában tanuló költségeit fizették. Az így megtakarított összegből az általános iskolások osztálylétszámát csökkentették. Belekezdtek egy független szektor kiépítésébe, vagyis a hagyományos független (independent) magániskolák mellett részben független fenntartású középiskolák kiépítésébe. Ezek finanszírozása vegyes, állami (tőkefedezet) és magánforrásokat (szponzorok) is bevonnak, de a helyi önkormányzatok (LEAs) ellenőrzése nem terjed ki rájuk. Később módosították az iskolai követelményeket és az egyéb szerkezeti és müködési kereteket (finanszírozás, ellenőrzés) $\left(1998^{12}\right)$. Az ezt szabályozó törvény sarokpontja az oktatás színvonalának emelése, aminek érdekében a gyenge tanulmányi eredményeket igyekeztek erőteljesen csökkenteni. A hátrányos helyzetủ területeken lévő iskolákból ún. Oktatási akció zónákat (Education Action Zones) jelöltek ki, állami támogatásokat és vállalati szponzorálást ígértek számukra, ösztönözték őket az innovációra és a nemzeti tantervtől is eltekintettek. Ugyanakkor fenntartották az iskolai specializációnak álcázott szelektív konzervatív politikát.

Az oktatási rendszer kritikusai szerint mindkét intézkedés arra ösztönözte az iskolákat, hogy a tanulókat képességeik alapján kiválogassák, ami erősítette az iskolák közötti különbségeket és az oktatási egyenlőtlenségeket (Chitty 1998).

Ehhez az időszakhoz köthető az ún. speciális föiskolák (city academies) elindítása, amely pártokon átívelö programmá vált. A független iskolák (magániskolák) bővitését még az előző kormány kezdte el, amikor harminc technikai akadémiát alapítottak; melyek széles körű összefogáson alapultak (adományok, egyház, kormány, üzleti szereplők), s kiváltották a rosszul müködő hagyományos típusú iskolákat. Alapításuk egyre növekvő költségekkel járt, ugyanakkor a tanulói teljesítményt ezekkel sem sikerült jelentősen javítani.

A 16-19 éves korosztály oktatási szükségleteinek biztosítására a 2000. évi Learning and Skills Act ${ }^{13}$ új kormányzati szervet bozott létre (Learning and Skills Council for England), ami szakmai ajánlásokat, módszertani eszközöket, tananyagokat dolgozott ki, valamint összehangolta és egységesen kezelte a szakképzés forrásait.

A szakképzés színvonalának javítására a következő három reformintézkedést fogalmazták meg, melyek jelentősen megemelték az óraszámokat, amihez azonban nem állt rendelkezésre megfelelő tanári kar:

- nyolc GCSE tantárgy mellett új, hibrid GCSE biztosítja, hogy a tanulók az akadémiai vagy alkalmazott pálya irányába lépjenek tovább;

- a Modern Apprenticeships rendszer bővítése (alap-, haladó és felső szint);

11 Ezeket (comprehensive schools) 11-16/18 éves korúak számára hozták létre. Felvételi nélkül lehet ide bejutni. Célja az oktatás demokratizálása, a korai kiválasztási mechanizmusok kiküszöbölésével egyenlö esélyeket teremteni minden gyermek számára.

12 Kiválóság az iskolában - 1998 School Standards and Framework Act: www.educationengland.org.uk/ documents/acts/1998-school-standards-framework-act.pdf

132000 Learning and Skills Act: www.educationengland.org.uk/documents/acts/2000-learning-skills-act.pdf 
- a GCSE (általános középiskolai tanúsítvány) és a GCE Advanced-level (továbbtanuláshoz szükséges általános tanulmányi bizonyítvány) végzettségeket egyenlő értékűnek kell tekinteni, növelve ezzel a szakképzés státuszát.

Egy kormányzati jelentés szerint a reformok ellenére 16 éves korban továbbra is kevesen mentek a szakképzésbe (Tomlinson jelentés $2004{ }^{14}$ ). Ugyanez a dokumentum gyengének találta a szakképzésben résztvevők funkcionális matematika- és írástudását, kommunikációkészségét, valamint IKT-képzettségét. A szakképesítések presztízse sem javult. A jelentés legfontosabb javaslatát, az új, moduláris végzettségek bevezetését a Brit Ipari Szövetség elutasította, így ezt követően csak korlátozott reformot vezettek be. A Tomlinson jelentés szakképzés fejlesztésére irányuló megállapításait végül az ellenzéki toryk támogatták, a munkáspártiak ugyanakkor nem, így a kormány elmulasztott egy lehetőséget arra, hogy olyan koherens és befogadó, átfogó (comprehensive) képzési rendszert alakítson ki a 14-19 évesek számra, melyet az oktatási szakma egésze támogat (Hodgson-Spours 2005).

A kormányzati ciklus utolsó harmadában az akadémiák - mint államilag kezdeményezett és támogatott, és szponzorok által finanszírozott független iskolák - továbbra is a szakképzés fejlesztésének legfontosabb intézményei maradtak: a velük kapcsolatos kritikák ellenére Blair bejelentette, hogy 400-ra emelik a számukat, a szülőket és tanulókat pedig jobban bevonják a követelmények kialakításába, valamint egyéb müködési kérdésekbe. A kormány olyan iskolarendszert vizionált, amiben az iskolák önállósága nagy hangsúlyt kap, magánszponzorok támogatják őket, ellenőrzik a saját maguk által kidolgozott tantervüket, és önirányító, önellenőrző módon működnek. A rosszul teljesítő iskolákat megszüntetik, továbbá partnerségi együttmüködések kialakítását szorgalmazzák az iskolák között a tapasztalatok megosztása érdekében. A javaslatok éles vitákat váltottak ki, és a kormány szembekerült az állami iskolák privatizációját mélyen elutasítók táborával, akik ragaszkodtak az ún. demokratikus elszámoltathatóság rendszeréhez (a szülők, a tantestület, a helyi hatóság lehetősége az oktatásra fordított költségek elszámoltathatóságára, az oktatási teljesítmények számonkérésére). Végül ezt a javaslatot is tory támogatással, nagy többséggel fogadták el. ${ }^{15}$

A Munkáspárt Blair lemondása után folytatta a reformokat. Felemelték a tankötelezettséget 18+ éves korra, amivel növelték a 16 év fölöttiek részvételét az oktatásban. Ehhez források kellettek, valamint olyan tananyag, ami hozzájárul az újonnan bevont rétegek munkahelyi esélyeinek növekedéséhez. A feltételeket A Gyakornoki rendszerröl, készségekröl, a gyermekröl és a tanulásról szóló törvény teremtette meg (Apprenticeships, Skills, Children and Learning Act, 2009), melyben új szolgáltatásokat, intézményeket alakítottak ki a 14-19 éves korosztály számára.

A kormány az akadémiák létrehozását/müködését változatlanul sikertörténetként állította be, bár egyre nehezebben találtak ezekhez támogatókat: „Az akadémiákkal a hátrányos helyzetü településeken erősítették a hátrányos helyzetű iskolákat, melyek, gyorsabb növekedést értek el, mint más iskolák" - írta egy szakíró. (Ed Balls, The Guardian, 2008. febr. 29.) A továbbképzési rendszeren belül ezekben található a legtöbb

\footnotetext{
Tomlinson jelentés 2004: www.educationengland.org.uk/documents/pdfs/2004-tomlinson-report.pdf

15 2006. évi oktatási és ellenőrzési törvény: www.educationengland.org.uk/documents/acts/2006-educationand-inspections-act.pdf
} 
lemorzsolódásban veszélyeztetett, illetve végzettség nélkül kimaradó tanuló. Állítása szerint a gazdasági válság a költségvetés csökkentését eredményezte, ami az oktatásra is kihatott, többek között a kisegítő munkaerő foglalkoztatása is veszélybe került. Az Ofsted átfogó vizsgálata szerint ${ }^{16}$ azonban az iskolák teljesítménye mindent egybevetve érzékelhetően javult a baloldali kormányzás időszaka alatt.

Az időszak értékelését végző Nuffield jelentés (Nuffield Review $2009^{17}$ ) szerint a reformok ellenére a szakképzést továbbra is a szerény részvételi arány és nagy lemorzsolódás jellemezte, aminek következtében továbbra is magas a nem tanuló, nem dolgozó fiatalok (NEET) száma. Hangsúlyozta, hogy az okok nemcsak a sokat hibáztatott, „agyonreformált” oktatásban keresendőek, hanem egyéb gazdasági-társadalmi tényezőkkel is összefüggenek. Az alkalmazott teljesítménymutatók nem tükrözik a célokat, értékeket, nem veszik figyelembe az iskolák különböző körülményeit, eltérő küldetéseit. A leginkább rászoruló tanulók rosszabb minőségű, rövidebb, olcsóbb képzéseket kapnak. A továbbképzési (Further Education - FE) szektor fontos szerepet tölt be a második esély megteremtésében, mégsem kap elég elismerést és finanszírozást. Nem elég átlátható a kínálatuk, ami különösen a szakképzések terén lenne fontos. A dokumentum részletes és innovatív javaslatokat fogalmaz meg, hangsúlyozva a tantervek lokális fejlesztését és értékelését.

„A kritikák ellenére összességében mégis elmondható, hogy a munkáspárti kormányzás idején a vizsgaeredmények javultak, mind a matematika, mind az angol tantárgy esetében. A Munkáspárt technológiai beruházásai azt jelentették, hogy sok iskolai tanterem számítógépekkel, elektronikus táblákkal és egyéb eszközökkel jól felszereltté vált. $\mathrm{A} z$ iskolákban nőtt a támogató személyzet száma is, így korábban elképzelhetetlen mértékben kaphattak személyes segítséget és kiscsoportos fejlesztést a gyermekek, amit nem szabad alábecsülni." (Chitty 2009: 249-250.)

$\mathrm{A} z$ intézkedések ugyanakkor nem eredményezték az oktatási különbségek csökkenését a szakképzésben. Az iskolákat privatizálták, vagyis a helyi oktatási hatóságok szerepe csökkent, az egyházaké pedig nőtt. Az iskolai rangsorok, a tesztelés, az Ofstedellenőrzés óriási nyomást gyakorolt az iskolai munkára, az iskolai verseny pedig rontotta a gyengébb tanulók helyzetét, mert az iskolák igyekeztek tőlük megszabadulni. A szülők és a pedagógusok szervezetei mellett számos baloldali oktatási szakember kifejezte csalódottságát a kormány oktatási intézkedéseivel kapcsolatban (Curtis 2009; Mortimore 2009; Wrigley 2014).

\section{A koaliciós kormány minöségpolitikája a szakképzésben (2010-2015)}

A Cameron vezette konzervatív ellenzék már a választási programjában nyilvánosságra hozta oktatási programját $A$ léc emelése, a hátrányok felszámolása, 2010 (Raising the bar, closing the gap) címmel, amiben előrevetítik, hogy a konzervatív párt vissza kívánja állítani a hagyományos tényalapú oktatást. Az elképzeléseket azonnal megkérdőjelezték egyes szakemberek, szakpolitikusok, és a pedagógusok is, hiszen az oktatási eredmények érzékelhetően javultak a 2000-es évek elején.

\footnotetext{
16 www.educationengland.org.uk/documents/pdfs/2010-ofsted-national-strategies.pdf

17 www.educationengland.org.uk/documents/pdfs/2010-ofsted-national-strategies.pdf
} 
A legfontosabb célkitűzése ennek a kormánynak is az oktatási egyenlőtlenségek csökkentése volt: a hátrányos helyzetű fiatalok felkarolása, valamint a szakképzés minőségének javítása. A megvalósítás érdekében átfogó reformokat jelentettek be szigorúbb követelmények, szabályok bevezetésével, valamint széles társadalmi összefogással új, független iskolákat kívántak létrehozni. Az oktatási szakemberek jó része már a program kihirdetésekor megkongatta a vészharangot, és nem kevesebbet állítottak, minthogy a neoliberális szellemü szerkezetátalakítás (közkiadások csökkentése, akadémiák létrehozása), a centralizálás és az iskolák privatizálása nem más, mint az 1988-as program megvalósítása és a thatcherizmus továbbgördítése (Stevenson 2012; Fisher 2012).

A szakképzésre irányuló felülvizsgálat (Wolf Review 2011 ${ }^{18}$ ) éles kritikát fogalmazott meg az előző kormány szakképzési reformjáról. Eszerint a 16-19 éves korosztály túlnyomó része ugyan teljes munkaidős iskolarendszerủ képzésben vett részt 18 éves koráig, de ezalatt csak alacsony szintű végzettséget szereztek, melyeket nem tudtak hasznosítani a munkaerőpiacon. Javasolták a közismereti tárgyak (matematika, angol) 16 éves kor fölötti oktatását és a fiatalok munkatapasztalat-szerzésének támogatását. A gyakornoki férőhely számának növelése mellett, a 16-18 évesek számára is színvonalas munkahelyi gyakorlat biztosítását látták szükségszerünek.

Gove oktatási miniszter politikája szakított minden korábbi konzultációs gyakorlattal, szakmai viták nélkül vezették be az akadémiák fejlesztési programját, és a működésüket teljesen kivették az önkormányzatok és a szülők ellenőrzése alól. A szülők és a pedagógusok tiltakozása ellenére pár hét alatt páratlan centralizációt hajtottak végre. Az oktatási kiadások jelentős csökkentése miatt felfüggesztették többek között az iskolafelújítási programot és a szakképzési szolgáltatásokat. Ennek ellenére Gove egy új, vitatott, tandíjmentesen müködő iskolatípust vezetett be, a svéd mintán alapuló, ún. szabad iskolákat (free school). Ezen túlmenően a 2011-es oktatási törvény ${ }^{19}$ újabb átfogó változásokat hozott a rendszerbe: átalakították a nemzeti alaptantervet, a képesítési rendszert, bevezették a szakképzési és karriertanácsadás szolgáltatását, hogy csak a szakképzéshez kötődőeket említsük. Ugyanabban az évben új, szigorúbb tanári követelményrendszert vezettek be, miközben engedélyezték a szabad és a független iskoláknak, hogy képesítés nélkül is alkalmazhassanak embereket az oktatásban, ami egyértelműen a költségcsökkentést célozta. Mindez növelte a tanárok és a szülők elégedetlenségét.

A 14-19 éves korosztály számára új, teljes munkaidős szakképző iskolákat alapítottak University Technical Colleges elnevezéssel (UTC). Ezek speciális szabad iskolák, melyekben egyesítették az egyetemek akadémiai, elméleti képzéseit a mérnöki, tudományos szakképzéssel (Zolnai 2014). A szakképző intézmény, az egyetem és egy szakképzésben érdekelt cég közösen finanszírozza és müködteti az oktatást, jól felszerelt, magasan kvalifikált tanárokat alkalmaznak, többféle szakterületen kínálnak GCSE vizsgákat. A munkahelyi szakmai képzést az együttműködő cég biztosítja. Müködésük hét éve alatt a koncepció nem nagyon működött, és egyre inkább az alulteljesítő tanulók

18 Review of Vocational Education: www.educationengland.org.uk/documents/pdfs/2011-wolf-reportvocational.pdf

19 „A tanítás fontossága”: www.educationengland.org.uk/documents/acts/2011-education-act.pdf 
célpontjaivá váltak. Emiatt több UTC-t be kellett zárni, mert senki nem teljesített C vagy magasabb szintű GCSE vizsgát. ${ }^{20}$

A 2010-es koalíciós kormány alapjaiban rendezte át a szakképzési rendszert Angliában. A kormány beszámolói szerint emelték a színvonalat, fejlesztették a nem megfelelő iskolákat, több mint 250 új, szabad iskolát hoztak létre, melyek a leginkább rászoruló tanulók számára nyújtanak magas színvonalú képzést. A tények azonban azt mutatják, hogy az akadémiák és a szabad iskolák teljesítménye és gazdálkodása elmarad az elvárásoktól. A helyi hatóságok (LEA) szerepét tovább csökkentették, sokak szerint korszerütlen nemzeti tantervet vezettek be. A teszteket, értékeléseket, vizsgakövetelményeket szigorították, és több ezer szakmát kivezettek a képzési rendszerből. A megnövekedett elvárások és adminisztratív terhek miatt egyre nehezebb a megfelelő felkészültségű tanárokat megtalálni és megtartani, amihez az iskoláknak eltérő lehetőségei vannak területi elhelyezkedésüktől függően. A szakképzésben megnövekedett közismereti óraszámokhoz szükséges munkaerő fizetését az iskolák nem tudják kigazdálkodni.

\section{Theresa May koalíciós kormánya (2015-2019)}

A szakképzési rendszer szakmai bírálói és a munkáltatók szerint is a rendszer megérett a változásra, az érintettek azonban gyakran úgy érzik, hogy az oktatás a politikai döntéshozók játszóterévé vált. Az újabb reform szakmai hátterét a Sainsbury jelentés (Sainsbury Review 2016) és A Lordok Háza Társadalmi Mobilitás Bizottságának vizsgálata (House of Lords 2016) biztosította. Ebből kiderült, hogy a korábbi reformok ellenére a hátrányos helyzetű fiatalok nem jutnak elegendő információhoz a szakképzés kínálatáról, tartalmáról és az elhelyezkedési lehetőségekről, ami rossz döntéseket és sikertelen tanulási utakat eredményez. Megállapítása szerint, ha a továbbképzési rendszer nem képes a fiatalokat a foglalkoztatás irányába segíteni és piacképes képesítésekhez juttatni, akkor a tankötelezettség 18 éves korra való emelése csak időpazarlás.

A szerzők rámutattak, hogy a korábbi kormányzati beavatkozások csak a szociális létra tetejére és aljára összpontosítottak. Egyrészt a GCSE A szintű vizsga eredményeinek javításával az egyetemi hozzáférés bővítését érték el, másik oldalról azokat a fiatalokat támogatták, akik kimaradtak az oktatásból és a munkaerőpiacon sem jelentek meg (NEET). Elemzésükben figyelmen kivül hagyott csoportnak nevezik az 1., a 2. és a 3. szintü ${ }^{21}$ szakmai képzések tanulóit. Ezek a fiatalok motivált, átlagos képességű tanulók, de lemondanak a felsőoktatásról, mert nem tudnak vagy nem akarnak élni a tanulmányi hitelekkel. A munkába való átmenetet az ő számukra is segíteni kell, amihez a továbbképzési rendszernek (FE) forrásokat kell kínálni a kötelező oktatás bővítésével.

Az oktatás funkcióit csökkenő finanszírozás és emelkedő egyenlőtlenségek között kell megvalósítani. Ezt csak drasztikus, merész átalakításokkal lehet megvalósítani, az

20 https://www.telegraph.co.uk/education/2017/02/14/technical-colleges-failure-admits-formereducation-secretary/

${ }^{21} \mathrm{~A} z$ angol szakmai képzések minősítési rendszere az egyszerű, szakmai felügyelet mellett végezhető tevékenységekre való jogosultságtól a legmagasabb tervező, fejlesztő, elemző önálló kutatói tevékenységekig nyolc szintbe sorolja a minősítéseket. Az első három szint a középfokú képzésekben megszerezhető minősítéseket tartalmazza. Ezek többnyire valamilyen részfeladat elvégzésére, illetve szakmai felügyelet mellett végezhető munkakörökre készítenek fel. 
igazságtalan régi rendszer bütykölgetése nem vezet eredményre, mondják a program támogatói (Reay 2017). Ennek szellemében indították el $A$ szakképzés és a felnöttoktatás nemzeti reformja címü programot 2016-ban ${ }^{22}$ Ennek elemei között találjuk A Funkcionális készségek reform programját, a Müszaki és továbbképzési törvényt, ${ }^{23}$ a T-szintek kidolgozását a 16 év feletti korosztály számára és az államilag támogatott gyakornoki ösztöndíjrendszert. Ezzel párhuzamosan új, független testületet alapított a kormány Institute for Apprenticeships néven, ami a munkáltatók által vezetett reformokat és a gyakornoki képzések (Apprenticeships) minőségét támogatja.

A tartalmi kérdések mellett az irányítás és finanszírozás is átszerveződött. Ahogy azt a tanügyigazgatás kapcsán korábban már említettük, 2017-től a közoktatás és a szakképzés irányítását és finanszírozását egységesen az Oktatás és Szakképzés Finanszírozási Ügynökség (Education and Skills Funding Agency) látja el. A folyamat fontos eleme a már szintén tárgyalt ellenőrző hatóság, az Ofsted müködésének új rendszere is (2019). 2019 elején vált elérhetővé a Stratégiai föiskolai fejlesztési alap (Strategic College Improvement Found - $\mathrm{SCIF}^{24}$ ), ami az iskolarendszerű szakképzés minőségét, illetve a tanulók egyéni sikerességét hivatott emelni.

A funkcionális készségek reformprogramja (Funcional Skills Reform Programme), az újonnan meghatározott matematika és angol követelményrendszerre épül, a célja a közismereti tárgyak és a tanulási készségek erősítése az óraszámok és a vizsgakövetelmények növelésével.

A Müszaki képzettségek új rendszere (T Level Action Plan ${ }^{25}$ ) (2018-2021) 13000nél is több régi szakmai minősítés kivezetésével jár. Helyettük 15 új szakmacsoportot alakítottak ki. A kapcsolódó szakmai sztenderdek, képzési tartalmak kidolgozása jelenleg is zajlik. ${ }^{26}$ Erősítik a matematika, az angol és az idegen nyelvek tanulását, ötven százalékkal növelik az órák számát, ami még kiegészül 45 nap szakmai gyakorlattal.

A reform másik fó pillére a gyakornoki képzés (Modern Appreticeships, 2020-tól English Apprenticeships). Mivel a munkáltatók, munkahelyek részvétele a szakképzésben a 2007-es válságtól kezdve drámaian csökkent, ezért a gyakornokok foglalkoztatását állami forrásokkal ösztönzik. ${ }^{27} \mathrm{~A}$ gyakornoki programban való részvételre és az ösztöndíjak igénybevételére a munkáltatók pályázhatnak. Ezzel a kevésbé aktív kis- és középvállalkozói réteget is szeretnék bevonni ezekbe. A számvevőszék pénzügyi szakemberei szerint aggodalomra ad okot, hogy a rendszer a jelenlegi keretek között hoszszú távon fenntarthatatlan, a pénzek felhasználása ellenőrizetlen, megtérülésük kétséges (Cadmen 201928).

22 National Reforms in Vocational Education and Training and Adult Learning: https://eacea.ec.europa. $\mathrm{eu} /$ national-policies/eurydice/content/national-reforms-vocational-education-and-training-and-adultlearning-75_en

23 2017. évi műszaki és továbbképzési törvény: www.legislation.gov.uk/ukpga/2017/19/contents/enacted

24 https://www.gov.uk/government/news/final-round-of-strategic-college-improvement-fund-opens

25 T Level Action Plan 2018: https://assets.publishing.service.gov.uk/government/uploads/system/uploads/ attachment_data/file/779002/T_Level_action_plan_2018.pdf

26 Post-16 technikal education reforms T Level Action Plan (2017): https://assets.publishing.service.gov.uk/ government/uploads/system/uploads/attachment_data/file/760829/T_Level_action_plan_2017.pdf

27 English Apprenticeships: Our 2020 Vision: https://www.gov.uk/government/publications/apprenticeshipsin-england-vision-for-2020

28 https://feweek.co.uk/2019/05/22/apprenticeships-programme-out-of-kilter-with-dfes-own-objectivespac-warns 
A választási programokban a pártok az oktatási költségek emelésével számoltak, ami reálértéken minimális emelkedést, sőt bizonyos esetekben csökkenést jelentett. A kormány szakképzési reformjai a tervezett kiadásoknál lényegesen magasabb költséggel járnak, többek között az óraszámemelések miatt (Belfield-Sibieta 2017), és a gyakornoki képzés finanszírozása is problémás. Az alulteljesítő iskolák felzárkóztató programja további jelentős és több évre szóló költségvetési terhet jelent.

A reform előremutató összetevője az ellenőrzés (Ofsted) korábbi hibáinak kiküszöbölését célzó, fejlesztést támogató felülvizsgálati rendszer kialakítása. Elegendő forrás gazdaságos felhasználásával hosszú távon a szakmai képzések színvonalának emelkedése várható. Az aggodalmak viszont éppen a beavatkozások hosszú távú fenntarthatóságával, a finanszírozás bizonytalanságával kapcsolatosak. Kérdés, hogy a 2019-ben újjáalakult kormány mit kezd az oktatással, a szakképzéssel és az előző kormány által elkezdett reformokkal.

\section{Összegzés}

Az angol szakképzés átalakítása az oktatási rendszer fejlesztésének tágabb kontextusába illeszkedik, a 2016-ban indult reformok szervesen kapcsolódnak a kilencvenes évek modernizálási folyamataihoz (Neumann 2008), valamint a jobboldali koalíciós kormányzás és az azt megelőző, a Munkáspárt által jegyzett változtatásokhoz (Zolnai 2014). $\mathrm{A} z$ oktatási rendszer változtatásait többnyire a társadalmi különbségek csökkentésével indokolják, aminek az egyik eszköze magas képzési standardok, tantárgyi követelmények elvárása, másik oldalról pedig az oktatási különbségek csökkentése. Mindezt indokolja a gazdaság igénye a magasan képzett munkaerő iránt. A célokban tehát a jobb- és baloldali kormányok kevéssé tértek el.

A számtalan korszerü és haladó javaslatot megfogalmazó szakértői jelentések a lokális szempontok és szakképzés müködésére fordítható források bővítését hangsúlyozták. $\mathrm{A} z$ intézkedésekben, úgy tűnik, nehéz volt e szempontoknak teljes mértékben érvényt szerezni. A neoliberális értékrend, a centralizáció, a privatizáció, a standardok és az ellenőrzés emelése összeköti az egyébként más értékrendre és szavazóbázisra építő pártok oktatáspolitikáját. Lényeges különbség ugyanakkor a tanulók szükségleteinek megítélése (képzési követelmények és tartalmak), valamint a társadalmi párbeszéd, a szülőkkel, tanárokkal és szakemberekkel párbeszédre való támaszkodás. Az angol szakképzés tapasztalatai sok tekintetben hasznosíthatóak a hazai helyzet elemzése során.

\section{IRODALOM}

Barber, M. \& Mourshed, M. (2007) How Teb World's Bestperforming School Systems Coma out on Top. London, McKinsey and Company.

Benn, C. \& Chittr, C. (1996) Thirty Years On: Is Comprehensive Education Alive and Well or Struggling to Survive? London, David Fulton Publishers.

Belfield, C. \& Sibieta, L. (2017) Comparison of Parties Plans for Education Spending on 16-18 Year Old Sin England. London, Institute for Fiscal Studies. https://www.ifs.org.uk/ publications $/ 9281$ 
Burke, J. (2018) 14 Colleges Receive Cash from the Strategic Improvement Fund. FE Week, 29 March.

Cadmen, B. (2019) Apprenticeships Programme 'Out of Kilter' with Dfe's Own Objectives. PAC Warns.

Chitтy, C. (1998) Selection Fever. The Guardian, 13 October.

Chitтy, C. (2009) Education Policy in Britain (2nd edition). Basingstoke, Palgrave Macmillan.

Coleman, J. S. (1968) Academic Games and Learning. The Bulettin of de National Association of Secondary School Principals, Vol. 52. No. 325. pp. 62-72. ISSN 2471-3317

Curtis, P. (2009) The End of the "Bog-Standard" Comprehensive. The Guardian, 8 December.

Dearing Review (1996) Sir Ron Dearing: Review of Qualifications for 16-19 Year Olds Hayes. SCAA Publications.

Finegold, D., Keep, E., Miliband, D., Raffe, D., Spours, K. \& Young, M. (1990) A British Baccalaureate: Overcoming Divisions between Education and Training. London, Institute for Public Policy Research.

Fisher, T. (2012) The Myth of School Autonomy: Centralisation as the Determinant of English Educational Politics. FORUM, Vol. 54. No. 2. pp. 231-246.

Gillard, D. (2018) Education in England: A History. http://www.educationengland.org.uk/ history/ [Letöltve: 2019. 10. 17.]

Hodgson, A. \& Spours, K. (2005) Divide We Fail. The Guardian, 1 March

House of Lords (2016) Overlooked and Left Behind: Improving the Transition from School to Work for the Majority of Young People. (Report of Session 2015-16.) Authority of the House of Lords. https://publications.parliament.uk/pa/ld201516/ldselect/ ldsocmob/120/120.pdf [Letöltve: 2019. 10. 17.]

Imre A. (1995) Reform - Vizsgarendszerrel. Educatio, Vol. 4. No. 3. pp. 454-468.

Lawton, D. (2005) Education and Labour Party Ideologies 1900-2001 and Beyond Abingdon Routledgefalmer. Idézi: Gillard 2018.

Mortimore, P. (2009) Missed Opportunities and Mad Ideas: The Goverment's Legacy. The Guardian, 7 July.

Neumann, E. (2008) 20 év reform Angliában. Educatio, Vol. 16. No. 4. pp. 557-566.

Norris, E. \& Adams, R. (2017) All Change Why Britain Is So Prone to Policy Reinvention, and What Can Be Done about It. Institute for Goverment.

Nuffield Review (2009) Pring, R., Hayward, G., Hodgson, A., Johnson, J., Keep, E., Oancea, A., Rees, G., Spours, K. \& Wilde, S.: Nuffield Review, Education for All the Future of Education and Training for 14-19 Olds. London, Routledge. ISBN:9780415547222

Politeia Report (2018) Lawlor, S.: Reversing Decline: Vocational Education and Training for a Highly-Skilled Workforce. Press Release.

Reay, D. (2017) The State Education Is in: Recognising the Challenge of Achieving a Fair Educational System in Post-Brexit, Austerity England. FORUM, Vol. 59. No. 3. pp. 325-330.

Sainsbury Review (2016) S. Blagden, B. Robinson, S. West \& A. Wolf (eds): Report of the Independent Panel on Technical Education. London, DfE / Department of Education.

Stevenson. H. (2011) Coalition Education Policy: Thatcherism's Long Shadow. FORUM, Vol. 53. No. 2. pp. 9-194. 
White, J. (2010) Turning the Clock Back to Subject Slavery. TES, 5 February.

Wolf Review (2011) Wolf, A.: Review of Vocational Education: The Wolf Report. London, Department of Education.

Wolf, A., Sellen, P. \& Dominguez-Reig, G. (2016) Remaking Tertiary Education: Can We Create a System That Is Fair and Fit for Purpose? London, Education Policy Institute \& Kingstron College.

Wrigley, T. (2014) The Politics of Cuerriculum in Schools Policy Paper. London, Centre for Labour and Social Studies.

Young, M. (2008) Bring Knowledge Back in: From Social Constructivism to Social Realism in the Sociology of Knowledge. London, Routledge.

Young, M. (2011) The Return to Subjects: A Sociological Perspective on the UK Coalition Government's Approach to the 14-19 Curriculum. The Curriculum Journal, Vol. 22. No. 2. pp. 265-278.

Young, M. (2013) Overcoming the Crisis in Curriculum Theory: A Knowledge-Based Approach. Journal of Curriculum Studies, 2013. April.

Zolnai E. (2014) Az idők szava. Az angol továbbképzési és szakképzési rendszer kihívásai a XXI. század elején. Acta MedSoc, Vol. 5. Nos 14-15. pp. 151-189.

A cikk a Creative Commons Attribution 4.0 International License (https://creativecommons.org/licenses/ by/4.0/) feltételei szerint publikált Open Access közlemény, melynek szellemében a cikk bármilyen médiumban szabadon felhasználható, megosztható és újraközölhető, feltéve, hogy az eredeti szerző és a közlés helye, illetve a CC License linkje és az esetlegesen végrehajtott módosítások feltüntetésre kerülnek. (SID_1) 